\section{Nano level surface finishing technology of advanced ceramics - ELID (electrolytic in-process dressing)}

KAZUTOSHI KATAHIRA - RIKEN (The Institute of Physical and Chemical Research), Materials Fabrication Laboratory - katahira@elid.ne.jp

HItoshI ОнmoRI - RIKEN (The Institute of Physical and Chemical Research), Materials Fabrication Laboratory

Received: 19. 01. 2009. - Érkezett: 2009. 01. 19.

The present paper describes the highly efficient and precise ELID grinding method and presents a discussion on the ELID grinding process and the grinding characteristics of several kinds of ceramic materials. The following conclusions are obtained; (1) Good ground surface roughness and accuracy are achieved using the \#4000 metal-bonded grinding wheel in through-feed centerless grinding for $\mathrm{ZrO}_{2}$ optical fiber ferrules. (2) Efficient and precise grinding of spherical lens molds with cup wheels using the ELID process was proposed and tested in the present study. Our investigations revealed that ELID CG-grinding can be used to successfully achieve better surface roughness. (3) The ELID grinding method can be used to fabricate machined surfaces exhibiting desirable characteristics for hard AIN ceramics. The final finishing using a \#30000 wheel produced an extremely smooth ground surface roughness of $0.008 \mu \mathrm{m} \mathrm{Ra}$.

\section{Introduction}

Efficient precision grinding techniques for ceramics are required in order to mass-produce ceramic parts. New grinding techniques for ceramics that employ fine bonded superabrasive wheels and high-stiffness grinding machines have been designed in order to achieve high grinding efficiency and produce highquality ceramic parts. Ceramics are extremely hard to machine using conventional methods. Mirror finishing of these hard, brittle materials requires the use of diamond abrasives. Grinding in particular, compared with lapping and polishing, can be used to efficiently produce various geometric forms. A novel grinding technology, known as Electrolytic In-Process Dressing (ELID), which incorporates "in-process dressing" of metal-bonded grinding wheels, provides dressing of the metalbonded wheels during the grinding process, while maintaining continuous protrudent abrasive from superabrasive wheels [1-5]. The present paper describes the highly efficient and precise ELID grinding method and presents a discussion on the ELID grinding process and the grinding characteristics of several kinds of ceramic materials.

\section{Efficient and precision ELID centerless grinding of zirconia ceramics}

\subsection{Experimental set up for ELID centerless grinding of zirconia ceramic}

In this section, micro-fabrication grinding with ELID centerless grinding is proposed. In an experiment, we conducted efficient, high-precision grinding of zirconia ceramics using the ELID centerless grinder shown in Fig. 1. Cast-iron-bonded diamond wheels of mesh size \#170 for coarse grinding, \#1200 for intermediate grinding, and \#4000 or $\# 8000$ for finish grinding were used. The average grit size of the $\# 4000$ and \#8000 wheels were approximately 4 microns and 2
Kazutoshi Katahira (1973) Doctor Engineering (University of Ibaraki). He's senior scientist at RIKEN (The Institute of Physical and Chemical Research) since 2007, visiting scholar at UC Berkeley since 2009, and visiting scientist at Keio University since 2001. The author proposes a method for actively and efficiently implementing surface modifications (functionalization) to workpieces during precision fabrication (grinding/cutting). According to this method, a mechanical-chemical reaction phenomenon, yet to be sufficiently clarified, between tool material and workpiece material can be controlled. Research of this method is considered to be of very high technological value. And using this method, the author has succeeded in developing a micro-tool having a diameter of less than $1 \mu \mathrm{m}$. The author has published the highly valued results, and was a recipient of the 2008 F.W. Taylor Medal of CIRP. Since then, this method has been attracting considerable attention in production technology areas such as ultra-precision molds and bioimplant components.

Hitoshi Ohmori (1962) Doctor Engineering (Tokyo University). He's chief scientist at RIKEN (The Institute of Physical and Chemical Research). He's visiting professor at Saitama University (since 2002), at Tianjin University (since 2007) and at Hunan University (since 2007). He's guest researcher at Lawrence Berkeley National Laboratory (since 2008) and collaborative researcher at Keio University (since 2008). He's research subjects: nanoprecision mechanical fabrication processes for micro-structural/functional devices, ultrafine transcription and computational mechanics assisted processes, applications on micro-fabrication processes, research on tribofabrication processes.

microns, respectively. A chemical-solution-type grinding fluid was used as the medium for ELID. A specific pulse generator for ELID was used.

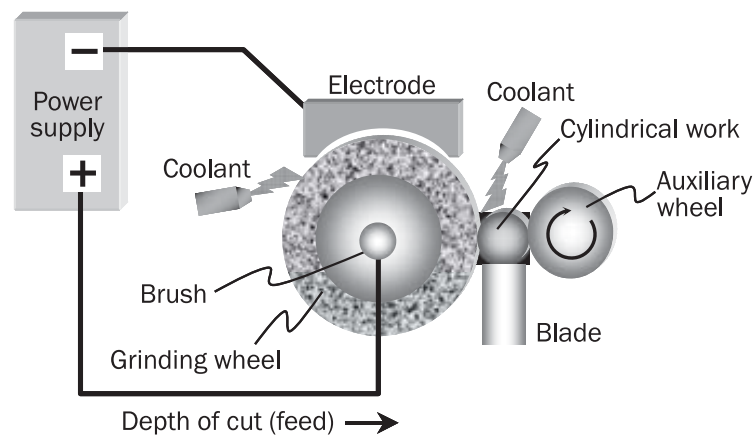

Fig. 1. ELID centerless grinder

1. ábra ELID csúcs nélküli csiszológép

\subsection{Results of ELID centerless grinding of zirconia ceramics}

Fig. 2. shows the relationship between in-feed speed and surface roughness in Rz using \#2000 and \#4000 wheels for the in-feed grinding of $\mathrm{Si}_{3} \mathrm{~N}_{4}$ and $\mathrm{ZrO}_{2}$ ceramics. Better results for $\mathrm{ZrO}_{2}$ were obtained with the \#4000 wheel at a lower in-feed speed of $0.04 \mathrm{~mm} / \mathrm{min}$. Since higher in-feed speeds result in higher productivity, efficient centerless grinding was achieved with ELID.

Fig. 3. shows the relationship between total depth of cut and surface roughness in the grinding of $\mathrm{Si}_{3} \mathrm{~N}_{4}$ and $\mathrm{ZrO}_{2}$ ceramics. The surface roughness remains approximately constant during 
the ELID grinding of both ceramics after a total grinding depth of 40 microns. A better surface finish was obtained using the \#4000 wheel for the grinding of the $\mathrm{Si}_{3} \mathrm{~N}_{4}$ ceramic workpieces.

Fig. 4. shows an example of surface profile obtained using the $\# 4000$ wheel for $\mathrm{ZrO}_{2}$ ferrules. A very smooth surface can be achieved. Table 1 . shows the surface roughness (Rz) and straightness (Rq) obtained for different wheel grits. A significant improvement in surface roughness and straightness was achieved by fine-grit wheels using the ELID technique. The ELID process enabled the maintenance of protruding fine grains, which realized stable and efficient grinding performance with high quality and accuracy, with regard to roundness and straightness, for example.

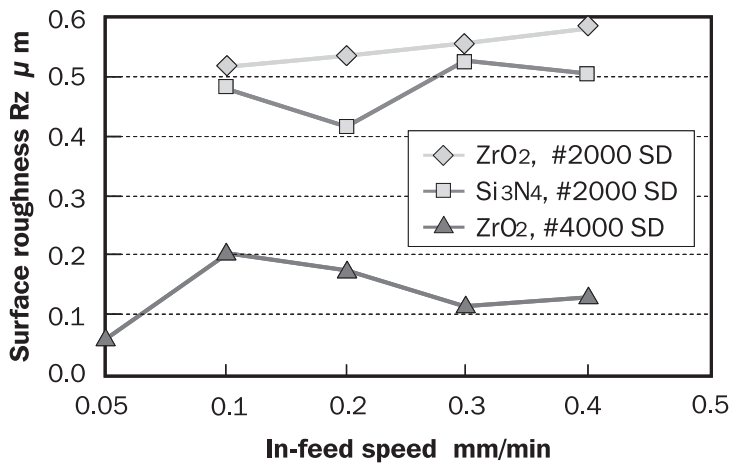

Fig. 2. Relation between surface roughness and in-feed speed

2. ábra Összefüggés a felületi érdesség és az elötolási sebesség között

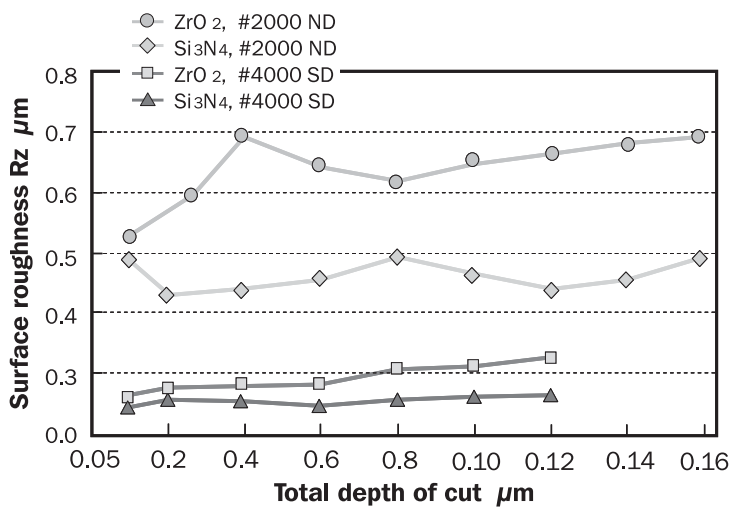

Fig. 3. Relationship between surface roughness and total depth of cut

3. ábra Összefüggés a felületi érdesség és a teljes vágási mélység között

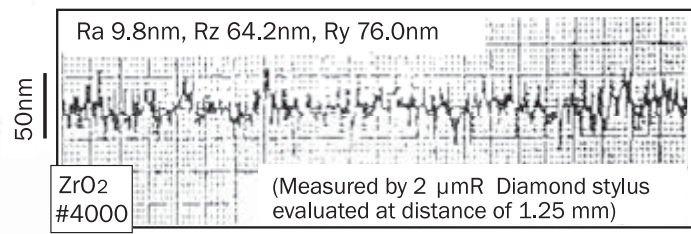

Fig. 4. Example of surface profile produced by $\# 4000$ wheel and ELID technique 4. ábra Példa a No. 4000 csiszolókoronggal és ELID technológiával kapott felület profilra

\begin{tabular}{ccccc} 
& $\mathbf{\# 8 0 0}$ & $\mathbf{\# 2 0 0 0}$ & $\mathbf{\# 4 0 0 0}$ & \#8000 \\
$\mathrm{Rz}$ & 0.90 & 0.26 & 0.066 & 0.072 \\
\hline $\mathrm{Rq}$ & 0.40 & 0.26 & 0.032 & 0.054 \\
\hline
\end{tabular}

Table 1. ELID centerless grinding results $(\mu \mathrm{m})$ by through-feed for $\mathrm{ZrO}_{2}$ ferrules 1. táblázat $\mathrm{ZrO}_{2}$ szoritógyürük ELID csúcs nélküli csiszolásával elért eredmények ( $\left.\mu \mathrm{m}\right)$

\section{ELID grinding characteristics for the machining of optical surface quality for ceramic spherical lens molds}

\subsection{Mechanism of ELID CG-grinding}

We have performed efficient, high-precision grinding of $\mathrm{SiC}$ and $\mathrm{Si}_{3} \mathrm{~N}_{4}$ ceramic spherical lens molds with cup wheels by the ELID process (hereafter called ELID CG-grinding) and have investigated the ground surface characteristics in detail.

Similar to the conventional ELID grinding system, ELID CGgrinding is essentially composed of the following elements:

- a cup metal-bonded diamond wheel,

- an ELID DC-pulse power source,

- a specific grinding fluid (which served as an electrolytic agent),

- a fixed copper electrode. Fig. 5. shows a schematic diagram of the ELID CG-grinding process.

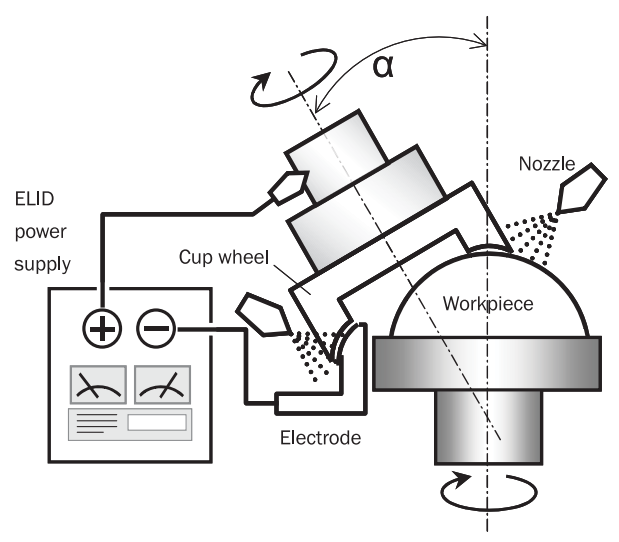

Fig. 5. Schematic of ELID CG-grinding

5. ábra Az ELID CG-csiszolás vázlata

The generating mechanism of the spherical surface ground with cup wheels was first introduced in 1920 by W. Taylor, an English scholar. As shown in Fig. 5., the workpiece is mounted on a work spindle, and the inclination angle $\boldsymbol{\alpha}$ between the axis of rotation of the workpiece and that of the wheel spindle is properly adjusted. Theoretically, the radius of curvature of the lenses that are produced can be calculated using the following equations:

$\mathrm{R}=\mathrm{Dsi} /\left(2^{\star} \sin \alpha\right)$ (for convex lens) (1)

$\mathrm{R}=\mathrm{Dso} /\left(2^{*} \sin \alpha\right)$ (for concave lens) (2)

where $\mathrm{R}$ is the radius of curvature of the lenses, Dsi is the internal diameter of the grinding wheel, Dso is the external diameter of the grinding wheel, and $\boldsymbol{\alpha}$ is the inclination angle of the axes of rotation between the workpiece and the wheel.

From a geometrical point of view, the parameters of dimensional error and shape accuracy in ELID CG-grinding consist mainly of the following:

- inclination deviation of the workpiece axis from the wheel axis,

- position deviation of the wheel-workpiece contact point from the workpiece rotation center in the $\boldsymbol{\alpha}$ plane,

- position deviation of the wheel axis from the $\boldsymbol{a}$ plane.

Among these, first and second affect the dimensional error of the lenses, and third influences the shape accuracy of the lenses. In contrast, wheel wear has no impact on the shape accuracy of the lenses that are produced. 


\subsection{Experimental setup for ELID CG-grinding}

Experiments were conducted on a specific $\mathrm{LOH}$ machine. Two cup cast-iron-bonded diamond wheels were used. The mesh size of the wheels was \#325 for coarse grinding and \#4000 for finish grinding. NEXSYS was used as an ELID coolant. A DC-pulse generator was used as the ELID power supply, with adjustable output voltages, currents, and duty factors. An open voltage of $90 \mathrm{~V}$ with a current of $20 \mathrm{~A}$ was set for these experiments. $\mathrm{SiC}$ and $\mathrm{Si}_{3} \mathrm{~N}_{4}$ ceramics were tested. Fig. 6. shows an overview of the experimental setup.

\subsection{ELID CG-grinding of ceramic spherical lens molds}

Fig. 7. shows the surface roughness and topography of the $\mathrm{SiC}$ spherical lens mold produced using ELID. Experimental conditions were a wheel speed of $5000 \mathrm{rpm}$, a workpiece rotation rate of $500 \mathrm{rpm}$, a feed rate of $30-50 \mu \mathrm{m} / \mathrm{min}$ for \#325 and 4-6 $\mu \mathrm{m} / \mathrm{min}$ for $\# 4000$, and a spark-out time of $60 \mathrm{~s}$. Although some initial defects appear on the surface, the ELID process achieves an improved surface finish, with a surface roughness similar to that obtained by loose abrasive processes such as polishing or lapping. In this case, the finished roughness was approximately $\mathrm{Ry}=73 \mathrm{~nm}$ and $\mathrm{Ra}=3 \mathrm{~nm}$, which demonstrates that ELID with extremely fine abrasives can produce highly smooth surfaces. This technique is also characterized by high precision and efficiency, attributable to the metal bonding of the abrasive. Finished examples are shown in Fig. 8. A mirrorlike mold could be finished in approximately $3-5$ minutes.

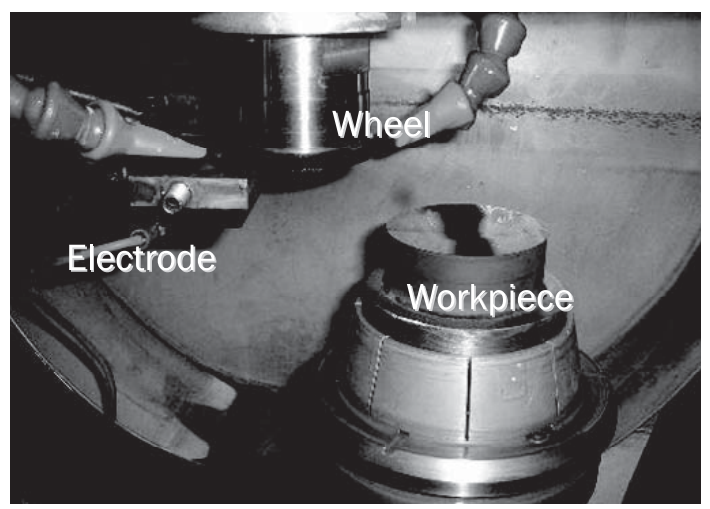

Fig. 6. Overview of experimental setup

6. ábra A kísérleti berendezés összeállitása

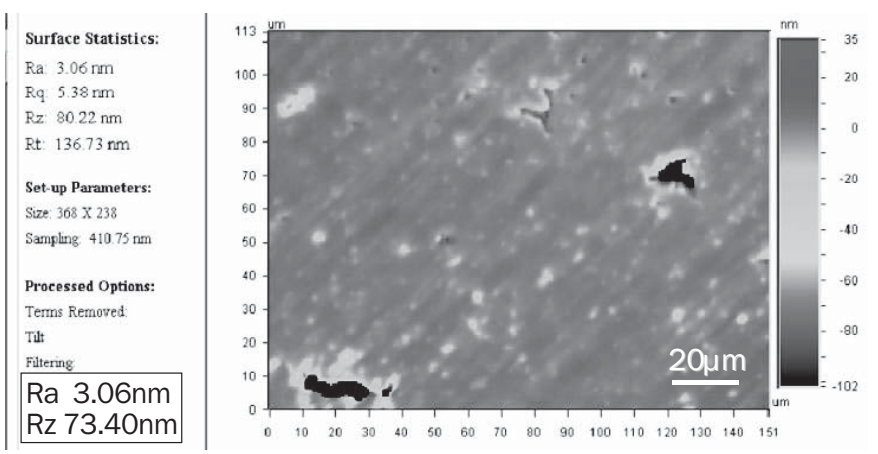

Fig. 7. Surface roughness and topography

7. ábra A felületi érdesség és a domborzat

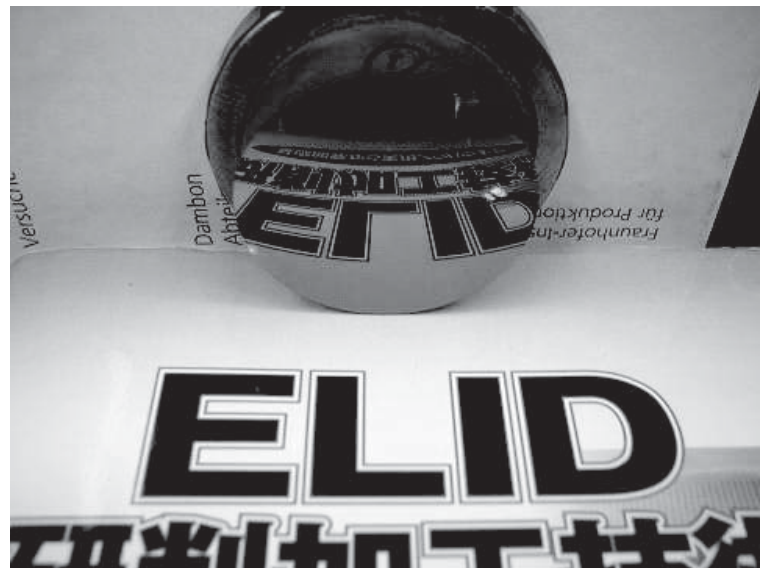

Fig. 8. ELID ground lens mold

8. ábra ELID technológiával csiszolt lencse-öntőforma

\section{ELID grinding characteristics of aluminium nitride $(\mathrm{AlN})$ ceramics}

\subsection{Experimental set up for ELID grinding of AlN ceramics}

Aluminum nitride (AlN) ceramics have excellent electrical insulation and dielectric properties, a high thermal conductivity that is approximately ten times that of alumina, as well as a thermal expansion coefficient that is close to that of Si. As such, AlN ceramics are anticipated to be used in semiconductor mounting boards, heat-dispersing substrates for power modules, and other heat-sink materials in a variety of high-value-added applications. In this section, we report the efficient, high-precision grinding of sintered AlN ceramics using the ELID process and describe the ground surface modifying characteristics in detail.

Table 2. lists the experimental conditions for ELID grinding. A precision rotational grinder was used for external grinding. The wheels used in this experiment were \#325, \#600 and \#1200 for rough grinding, $\# 2000$ and \#4000 for intermediate grinding, and $\# 8000$ and $\# 30000$ for finishing. The $\# 30000$ wheel had average grit size of approximately $0.3 \mu \mathrm{m}$. In addition, surface evaluation and testing were carried out on AIN, in which ELID grinding was performed in order to examine the surface properties and surface modifying effect.

Fig. 9. shows the results of surface roughness measurements for AIN subjected to ELID grinding. The obtained results indicate that the finer the grain size of the grinding wheel, the greater the improvement in the surface roughness. A dramatic improvement in the roughness of the ground surface was confirmed between the \#600 and \#2000 wheels. This is attributed to changes in the material removal mechanism between the two grains. By final-finish machining using \#30000 abrasive, a satisfactory surface roughness of $0.008 \mu \mathrm{m}$ Ra was obtained. Significant improvement in surface roughness and form accuracy was successfully achieved by fine-grit wheels using the ELID technique.

\subsection{Observation of the ELID ground surface}

Fig. 10. shows the results of SEM observations of the ground surfaces obtained with \#325 to \#30000 grinding wheels. The 
surfaces ground with the \#325 wheels demonstrate a rough processed state with the material removed by the breakdown of the grain boundary. On the surface ground with the \#1200 wheel, a small number of areas in which the material was removed by means other than the breakdown of the grain boundary were confirmed. However, in the same way as the surface ground with the \#325 wheel, most of the areas were removed in the brittle failure mode, in which the breakdown of the grain boundary is the principle mechanism. Conversely, the surfaces ground with the \#2000 and \#30000 wheels were processed to a smooth surface, with almost no breakdown of the grain boundary observed. SEM observations of machined surfaces confirmed that between rough machining with \#1200 abrasive and intermediate finishing with \#2000 abrasive, there exists a brittle-ductile transition point for aluminum nitride. In order to create a high-quality machined surface, the use of fine abrasive particles of at least \#2000 is essential.

\begin{tabular}{ll} 
Workpiece & Aluminumnitride (AIN) ceramics \\
Grinding machine & Precision rotational grinder \\
\hline Grinding wheel & $\begin{array}{l}\text { Cast iron bonded diamond wheel ( \#325, \#600, } \\
\text { \#1200, \#2000, \#4000, \#8000, \#30000) }\end{array}$ \\
\hline Grinding conditions & $\begin{array}{l}\text { Wheel rotation: } 2000 \mathrm{~min}^{-1}, \text { Work rotation: } \\
\text { 300 min }{ }^{-1}, \text { Depth of cut: } 2 \mu \mathrm{m} / \mathrm{min}, 1 \mu \mathrm{m} / \mathrm{min}\end{array}$ \\
\hline Grinding fluid & $\begin{array}{l}\text { Chemical solution type grinding fluid }(5 \% \text { dilu- } \\
\text { tion to water), Density: } 1.07 \mathrm{~g} / \mathrm{cm}^{3}, \mathrm{pH}(\mathrm{x} 50): \\
\\
\text { 10.0, Conductivity (x50): } 1230 \mu \mathrm{s} / \mathrm{cm}\end{array}$ \\
\hline Electrical conditions & Open voltage: $90 \mathrm{~V}$, Peak current: $10 \mathrm{~A}$, Pulse \\
& timing (on/off): $2 / 2 \mu \mathrm{s}$, Pulse wave: square \\
\hline
\end{tabular}

Table 2. ELID grinding conditions

2. táblázat Az ELID technológia paraméterei

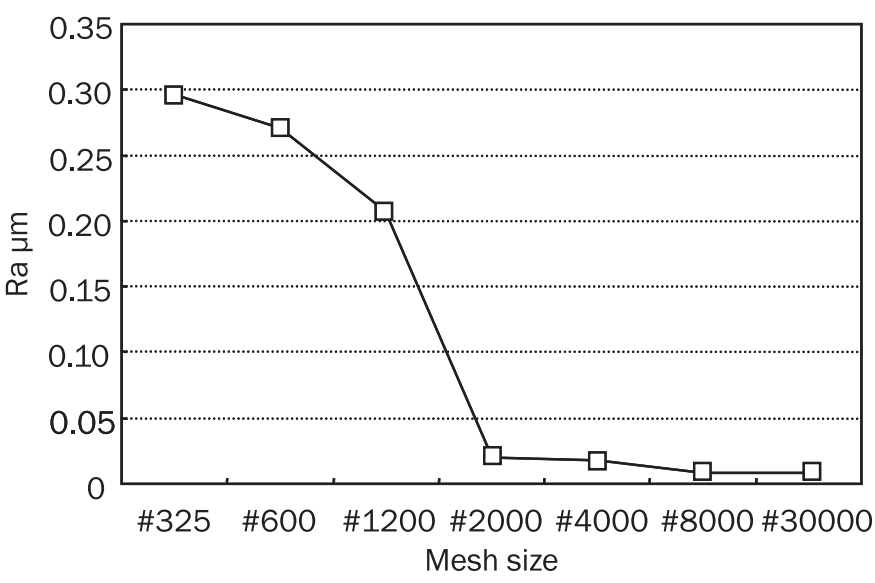

Fig. 9. Relation between mesh size and surface roughness

9. ábra A szitaméret és a felületi érdesség összefüggése

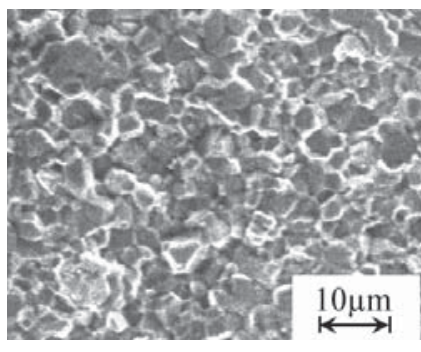

(a) \#325

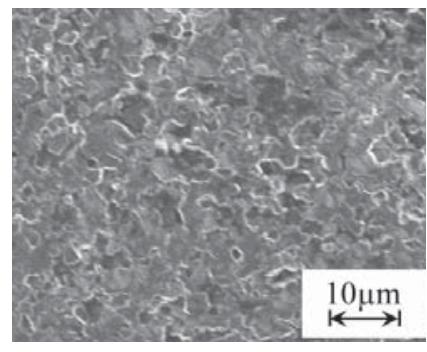

(b) $\# 1200$

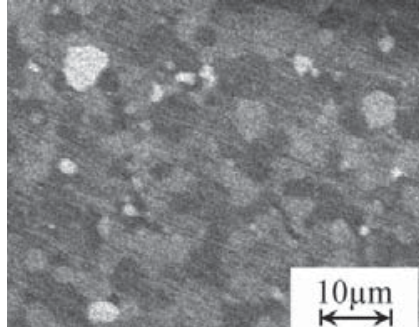

(c) $\# 2000$

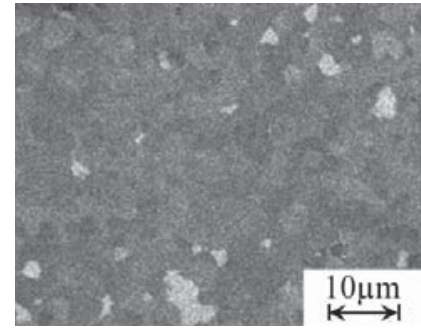

(g) \#30000
Fig. 10. SEM images of ground surface by ELID

10. ábra ELID technológiával csiszolt felület pásztázó elektronmikroszkópos felvételei

\section{Summary}

The following conclusions are obtained; (1) Good ground surface roughness and accuracy are achieved using the \#4000 metal-bonded grinding wheel in through-feed centerless grinding for $\mathrm{ZrO}_{2}$ optical fiber ferrules. (2) Efficient and precise grinding of spherical lens molds with cup wheels using the ELID process was proposed and tested in the present study. Our investigations revealed that ELID CG-grinding can be used to successfully achieve better surface roughness. (3) The ELID grinding method can be used to fabricate machined surfaces exhibiting desirable characteristics for hard AlN ceramics. The final finishing using a \#30000 wheel produced an extremely smooth ground surface roughness of $0.008 \mu \mathrm{m} \mathrm{Ra}$.

\section{References}

[1] Ohmori, H.: Electrolytic In-Process Dressing (ELID) Grinding Technique for Ultra Precision Mirror Surface Machining, International Journal of JSPE, Vol. 26, No. 4, 1992, pp 273-278.

[1] Ohmori, H, - I., D., Marinescu: Super-smooth Surfaces with ELID Technique, Abrasives, Vol. 8, No.9, 1998.

[1] Ohmori, H. - Katahira, K. - Uehara, Y., - Lin, W.: ELID-Grinding of Microtool and Applications to Fabrication of Microcomponents, Int. J. of Materials \& Product Technology, Vol. 18, No.4/5/6, 2003, pp 498-508.

[1] Katahira, K. - Watanabe, Y. - Ohmori, H. - Kato, T.: ELID grinding and tribological characteristics of TiAlN film, Int. Journal of Machine Tools \& Manufacture, Vol. 42, 2002, pp 1307-1313.

[1] Ohmori, H. - Katahira, K. - Mizutani, M. - Komotori, J.: Investigation on Color-Finishing Process Conditions for Titanium Alloy applying a New Electrical Grinding Process, Annals of the CIRP, Vol. 53, No.1, 2004, 455-458.

ELID (Electrolytic In-process Dressing) - a progresszív kerámiák nanométer nagyságrendű felületfiniselő technológiája

Ez a cikk ismerteti és megvitatja az igen hatékony és pontos ELID finiselési technológiát, és bemutatja többféle kerámiai anyag csiszolási jellemzôit. A levont következtetések: (1) A No. 4000 fémkötésú csiszolókorong használatával jó felületi érdességet és pontosságot értünk el a $\mathrm{ZrO}_{2}$ optikai szál szorítógyúrūk áteresztéses, csúcs nélküli csiszolása során. (2) A jelen kutatások során fazékkorongos csiszolást javasoltunk és próbáltunk ki gömbölyú lencsék öntôformáinak megmunkálásához az ELID folyamat alkalmazásával. A kutatási eredmények arról tanúskodnak, hogy a jobb felületi érdesség eléréséhez sikeresen használható az ELID CGcsiszolás. (3) Az ELID technológia alkalmazható a megkívánt jellemzôkkel rendelkezô felületû, kemény AIN kerámiák gépi csiszolásához is. A No. 3000 csiszolókoronggal végzett finiselés rendkívül finom felületi érdességet $(0,008 \mu \mathrm{m} \mathrm{Ra})$ eredményezett. 